\title{
anu \\ Quantifying the Spatial-Temporal Variation of Population Urbanization and Affordable Housing Land in China
}

\author{
Chunyan $\mathrm{He}^{1}{ }^{1}$, Ding $\mathrm{Li}^{2, *}$ and Junlin $\mathrm{Yu}^{3}$ \\ 1 School of Economics, Xihua University, Chengdu 610039, China; 1220200034@mail.xhu.edu.cn \\ 2 School of Public Administration, Southwestern University of Finance and Economics, Chengdu 611130, China \\ 3 School of Business Administration, Yonsei University, Seoul 03722, Korea; yujunlin98@yonsei.ac.kr \\ * Correspondence: liding@swufe.edu.cn; Tel.: +86-13980676565
}

check for updates

Citation: He, C.; Li, D.; Yu, J. Quantifying the Spatial-Temporal Variation of Population Urbanization and Affordable Housing Land in China. Land 2022, 11, 259. https:// doi.org/10.3390/land11020259

Academic Editors: Shaojian Wang, Yu Yang, Yingcheng Li and Rui Xie

Received: 29 December 2021

Accepted: 8 February 2022

Published: 9 February 2022

Publisher's Note: MDPI stays neutral with regard to jurisdictional claims in published maps and institutional affiliations.

Copyright: (C) 2022 by the authors. Licensee MDPI, Basel, Switzerland. This article is an open access article distributed under the terms and conditions of the Creative Commons Attribution (CC BY) license (https:// creativecommons.org/licenses/by/ $4.0 /)$.

\begin{abstract}
The governments of most countries are striving to coordinate residents' housing demands with the supply of land to achieve high-quality urbanization and improve residents' welfare. Based on the panel data of all Chinese provinces from 2010 to 2017, this study obtains 248 observations. It uses the coupling coordination degree, the Mann-Kendall trend test, and spatial autocorrelation methods to analyze the temporal and spatial variation of the coordination degree of population urbanization and affordable housing land supply. The study aims to clarify the temporal trend further and identify the spatial mismatch of affordable housing land resource allocation and apply a panel fixed model to determine its driving factors. The regional differentiation of the coordinated development level of population urbanization and affordable housing land in China's provinces is apparent. The overall spatial distribution characteristics of coordination are opposite to the development of its economic level. The Mann-Kendall trend test indicated that the coupling coordination degree had a significant upward trend nationwide. Moreover, the coupling coordination degree shows a strong positive global spatial correlation. The local spatial agglomeration characteristics of the coordination are significant and primarily manifested in high-high and low-low agglomeration. A negative correlation exists between the degree of coupling coordination and the dependence of local governments on land finance and housing prices.
\end{abstract}

Keywords: population urbanization; affordable housing; land supply area for affordable housing; land finance

\section{Introduction}

Urbanization has been a major global issue for centuries. Because of population migration, economic phenomena, and social phenomena, it is a necessary development process for countries worldwide [1]. While the beginning of the British Industrial Revolution brought about the rapid development of the global economy, it also accelerated the speed of population gathering in spaces, which led to the continuous acceleration of the worldwide urbanization process [2]. Compared to China, European and American regions mainly rely on immigrants to provide the fundamental driving force for production when developing industries. Therefore, when foreign populations migrate to European and American countries, the different immigration policies of each country limit the flow of migrant populations. As a country with a large population, China's economy is primarily driven by peasants' migration across various regions to cities with a high concentration of domestic economic activities to provide sufficient labor [3]. However, due to rapid economic development, problems such as the rise of urban housing prices, the uneven distribution of public services, and the lack of social security for migrants within cities have gradually emerged, which means that the housing problems of internal migrant workers, especially peasant workers, cannot be guaranteed. Relying only on economic dividends to attract migrants to big cities without providing them with corresponding guarantees is 
not truly urbanization. Urban migrants without hukous mainly include rural-to-urban and city-to-city migrants. Rural-to-urban migrants are typically born in rural regions and hold agricultural hukous.

In contrast, city-to-city migrants usually have a permanent hukou from one city. Still, they choose to live in another city to pursue better job opportunities, education, medical services, and so on. While the marketization of housing provision has greatly facilitated rural-to-urban migration and created millions of job opportunities for migrants, the upsurge in housing prices is making decent accommodation increasingly unaffordable [4,5]. Especially under the backdrop of climate change, the more vulnerable individuals and groups are, the weaker their ability to cope with the risks of climate change [6]. Migrants' access to land, employment, and public services are limited, meaning that they are becoming vulnerable. Climate change will further exacerbate the poverty and vulnerability of vulnerable groups, reduce welfare, and affect the urban land supply and even regional economic growth $[7,8]$.

In a fuller sense, urbanization in China refers to the urbanization of the population. Population urbanization has always been a matter of great concern for the Chinese government. China proposed the construction of a new type of urbanization as early as 2013, which is inseparable from providing affordable housing for the migrant population in the city. Only migrant groups obtain affordable housing in cities; it can be said that China has transformed into a new and high-quality population urbanization stage [9].

In recent decades, China has experienced strong economic growth, accompanied by rapid urbanization, accelerated population mobility, and increased housing prices. Faced with the growing issue of housing affordability in urban regions, the central government has introduced a series of affordable housing policies [10-12]. Since 2008, affordable housing programs in China have mainly included public rental housing (PRH), cheap rental housing $(\mathrm{CRH})$, economical and comfortable housing $(\mathrm{ECH})$, and capped-price housing $(\mathrm{CPH})$, with PRH taking the lead in the number of constructed units. The central government designs affordable housing policies to maintain social stability, and requires local governments to provide sufficient housing based on their financial capabilities. Therefore, local governments are responsible for constructing, funding, and allocating affordable housing [13]. Out of consideration for their interests, local governments are unwilling to invest too much capital and land in the construction of social housing, leading to an uneven distribution of social housing resources, which makes it challenging for them to meet the city's needs, and harms the welfare of residents.

Existing research primarily focuses on the spatial coupling relationship between urbanization and public services, such as education, the environment, and land use [14,15]. Few studies have examined the spatial mismatch between affordable housing land resource allocation and population urbanization. To fill this gap, taking the province as the study unit, and on the basis of panel data for all Chinese provinces from 2010 to 2017, this study obtained 248 observations. It used the coupling coordination degree, the Mann-Kendall trend test, and spatial autocorrelation methods to analyze the temporal and spatial variation of the coordination degree of population urbanization and affordable housing land supply. It also applied a panel fixed model (FE) to determine its driving factors. Furthermore, some implications have been proposed for increasing the coupling coordination between population urbanization and affordable housing land to improve residents' welfare and the quality of urbanization.

\section{Literature Review}

\subsection{Population Urbanization}

Global urbanization has shown a significant amount of momentum, leading to accelerated development, with the urban population surpassing the rural population [16]. According to the United Nations' world urbanization projections, only $30 \%$ of the global population lived in cities in 1950, whereas the urban population accounted for 55\% in 2018, and is predicted to reach $68 \%$ by 2050 [17]. Many scholars have studied the driving 
forces behind urbanization. Economic growth and industrial structure are core driving forces [18-20]. City size, resource allocation efficiency, productivity, employment rate, and public services are closely related to the level of urbanization [21]. Currently, the effect of climate change on urbanization has been the focus of research [22]. The quantitative methods of urbanization development include the index system method and the model method. The index system method measures urbanization development by evaluating a group of multidimensional indicators. This method combines social, economic, and environmental aspects, making it suitable for analyzing comprehensive research objects [23]. Compared to the index system method, the model method can study urbanization development more objectively and avoid many advanced assumptions. The relevant models mainly come from socioeconomic, ecological, systematic, and emerging sciences, such as the comprehensive gravity model, the Gram-Schmidt orthogonalization method, the CG-GSO model, and the DEA model [24-27]. Moreover, the model of the drivers of urbanization includes spatial lag, spatial error, spatial Dubin, and panel regression models [28].

In the United States, where population urbanization is relatively mature, although there is a large regional gap between the share of the U.S. states' GDP and the share of the continent's population in the U.S., the per capita GDP of each U.S. state is almost the same [29]. The urbanization of the United States began at the end of the 19th century. Driven by industrialization, the level of urbanization has increased rapidly. In the second half of the 20th century, the United States replaced Europe as the center of world economic development. At the end of the 20th century, the urban population of the United States further increased to 96.5 million, and the urbanization rate reached $63.6 \%$. Because of the development of the West, the urbanization gap between the East and West has narrowed, changing the unbalanced development situation [30]. Since 1950, the United States has achieved a high degree of urbanization, and the economic and social structure has undergone major changes. In 2000, the urbanization rate was $79.1 \%$, the output value of secondary and tertiary industries accounted for $95 \%$ of GDP, and the non-agricultural labor force accounted for $87 \%$ [31]. High-tech and modern service industries are becoming increasingly dominant in the urban economy. Changes in the economic and social structure have impacted the spatial distribution of the urban population and economy, and the metropolitanization and suburbanization of urban populations have become two prominent features of urbanization [32]. Compared to the United States, China's provinces account for a greater share of GDP, and the gap between each province's share of GDP and its population share is relatively large. This has led to a large gap in the per capita GDP of China's provinces, which shows that China's economic and population agglomerations are not synchronized.

Some scholars have also studied the relationship between population urbanization and land urbanization. In China, population urbanization can promote educational urbanization, which is mainly reflected in the migration of many school-age populations from rural to urban areas. Long-term economic growth depends on the continuous improvement of labor productivity and, under normal circumstances, the progress of labor productivity depends primarily on education. Regarding the importance of education, during the 100 years of the 20th century (the "American Century"), the basis for the United States to lead the world in technological innovation was education [33]. Lin et al. pointed out that the rate of land urbanization in China is significantly faster than that of population urbanization; however, the development quality of population urbanization is better than that of land urbanization, and these two gradually tend to develop in conjunction [34]. Ma and Liu found that the cultivated land occupation rate driven by investment is increasing, suggesting that the government should develop a supply policy for construction land following the changing trends of local population migration [35]. 


\subsection{Affordable Housing}

With the continuous development of China's economy and its increasing share of the global economy, housing in China's primary economic cities has gradually become an investment product and has lost its sense of residence. Thus, it is valued more as a financial asset. Simultaneously, with continuous urbanization, the imbalance between housing supply and demand has led to high housing prices. For ordinary low-skilled migrant laborers, it is challenging to own a house in the city. Concerning affordable housing, because of its relatively limited availability of affordable housing, each city government will tend to restrict the eligibility for affordable housing to the population with hukous when formulating related policies regarding affordable housing [36]. In other words, the threshold for obtaining affordable housing is relatively high. Simultaneously, there are more policy restrictions for permanent migrant residents in cities who want to relocate their household registration to the city where they are located. Various factors have increased the difficulty of social integration among migrant populations.

Among the substantial literature that discusses China's affordable housing issues, most researchers focus on policy changes and practices [37,38], analyze how inter-government structures have impacted affordable housing practices [39], or evaluate residential satisfaction in affordable housing through case studies [40-42], such as from the perspective of dwelling features, dwelling facilities, public facilities, neighborhood environment, housing policies, and the socio-demographic characteristics of affordable housing. Regarding the issue of local governments' affordable housing provision, Hu and Qian used a panel dataset of land supply in Chinese cities at the prefectural level and above to examine the factors influencing local governments' commitment to land supply for affordable housing. They found that cities with more dependence on land finance and higher fiscal autonomy were less likely to devote land to affordable housing construction. Their results suggest that reasonable housing provision in urban China cannot be successfully implemented unless local governments' reliance on urban land-based interests is weakened [43].

The existing literature primarily discusses the process of China's population urbanization and current problems from the aspects of driving factors, migrant population types, and entry barriers for the migrant population. Existing studies on affordable housing primarily use government policy formulation and China's hukou system as starting points for research. Current studies have provided a great deal of enlightenment, but there are few studies on the spatial allocation of population urbanization and affordable housing; this is the research area of this paper.

\section{Several Issues Relating to Urbanization in China}

\subsection{Hukou System}

China's hukou reforms are crucial to urbanization. The hukou system, an urban registration system introduced in 1958, has been promulgated as an official tool for controlling the free movement of people between urban and rural areas. Administrative regulations issued in 1982, known as "custody and repatriation" (C\&R), authorized the police to detain migrants if they did not have a local residence permit (hukou) or a temporary living permit in the city. Officers could then repatriate these "illegal migrants" to the settlements where their permanent hukou was issued [44]. Although the C\&R law was formally abolished in 2003, the hukou system remains in force, and continues to constrain population mobility. Urban migrants without hukous mainly include rural-to-urban and city-to-city migrants. Rural-to-urban migrants are typically born in rural regions and have agricultural hukous. While city-to-city migrants typically hold a permanent hukou from one city, they choose to live in another city to pursue better job opportunities, education, medical services, and so on. Moreover, even in the same city, urban residents and migrants experience different levels of housing welfare $[45,46]$. Urban residents with local permanent hukous have access to welfare benefits, such as unemployment insurance, health care, pensions, housing benefits, and even their children's right to enter local schools. Migrants without local hukous, 
however, experience levels of access to urban welfare benefits that are drastically different from permanent residents [47].

\subsection{Central Government and Local Government Conflicts on Housing Policy}

The real estate industry has been a strong driver of urbanization and economic growth in China. After fiscal decentralization, local Chinese government revenues became more dependent on land transfer revenue; for example, in 2016, the proportion of land transfer revenue was more than $50 \%$ of the local government's general public revenue in Guangzhou, Tianjin, Chengdu, Wuhan, Zhengzhou, and many other major cities. Similar to the United States and other developed countries, real estate taxes are a stable source of local revenue. However, in China, as all land is state-owned, there are no real estate taxes, which means that there is a tax reduction for housing transactions. This, in turn, means that local governments are more dependent on land transfer revenue; that is, high land prices can provide adequate revenue for local governments, with rising land prices directly leading to higher house prices which, in turn, drives a property boom and contributes to economic growth. Moreover, under the premise that the total supply of urban land is limited, affordable housing land is essentially supplied in the form of free allocation, which reduces the amount of land available for business use, which will undoubtedly reduce the local government's land fiscal revenue and affect its enthusiasm for the construction of affordable housing.

As the central government has been using the GDP growth rate as the main indicator for assessing local government operations, rapid real estate industry development is being encouraged by local governments [48]. However, high house prices can seriously restrict housing consumption and reduce the quality of life of residents. A rapid increases in housing prices could also result in a housing market bubble, which is not conducive to the stable development of the national economy. The central government does not want any excessive growth in housing prices; rather, it wants the housing market to develop steadily to ensure residential quality of life, sustainable economic development, and social stability. However, because local governments wish to obtain greater land transfer revenue and rapid, short-term economic growth, they do not want house prices to fall and supply affordable housing, which means that they are often unwilling to comply with central government policies that seek to tighten housing supply; therefore, conflicts emerge between the central and local governments [13].

\subsection{Spatial Mismatch between Population Urbanization and Public Services}

According to the ratio of the permanent population of each province to the nationwide population at the end of 2017 and the proportion of each province's GDP as part of the national GDP (Figure 1), the per capita GDP of each province in China is not balanced, which will cause the population to move to provinces with higher GDP to earn a higher income. On the other hand, provinces with better economic growth will place greater pressure on the migrant population, and the requirements for the supply of public infrastructure and affordable housing in such provinces will be higher. More developed provinces are constantly attracting migrant workers, suggesting that such provinces need more affordable housing construction to stabilize the sizable settlement requirement of the inflowing migrant population to ensure that China's population urbanization can proceed with high quality. From the data on the proportion of administration and public services land (Figure 2), we find that there is a certain spatial mismatch between China's population urbanization and basic public services, which is the core research focus of this article. 


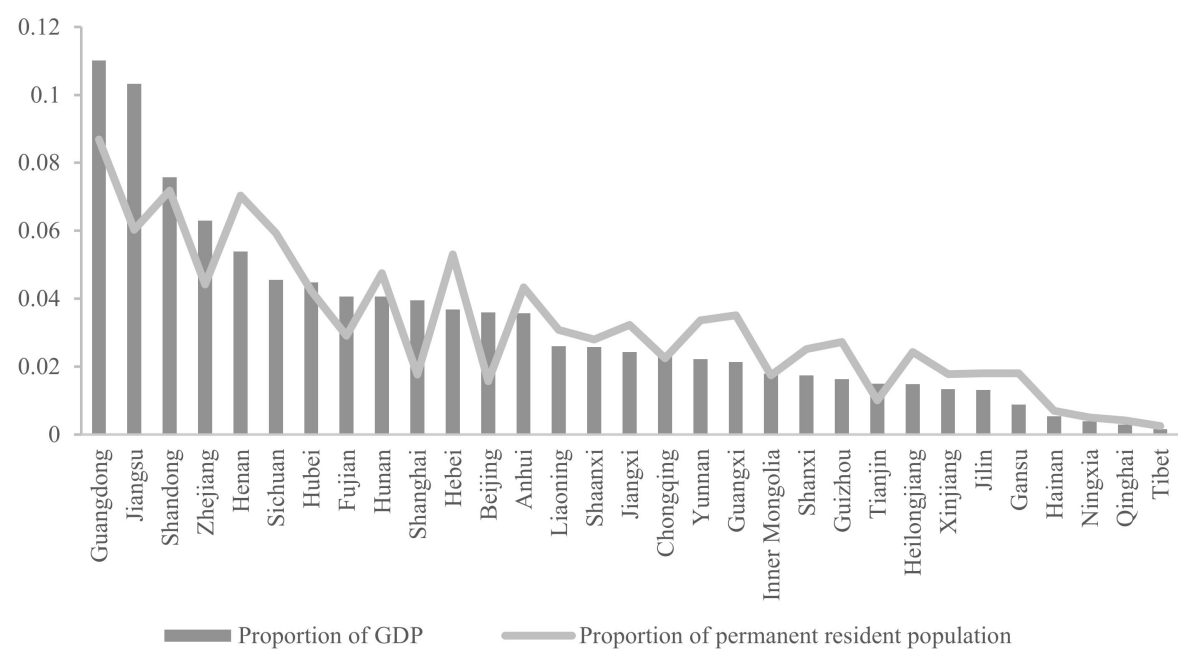

Figure 1. The proportion of GDP and permanent resident population in 2017 in Chinese provinces (data source: National Bureau of Statistics of China).

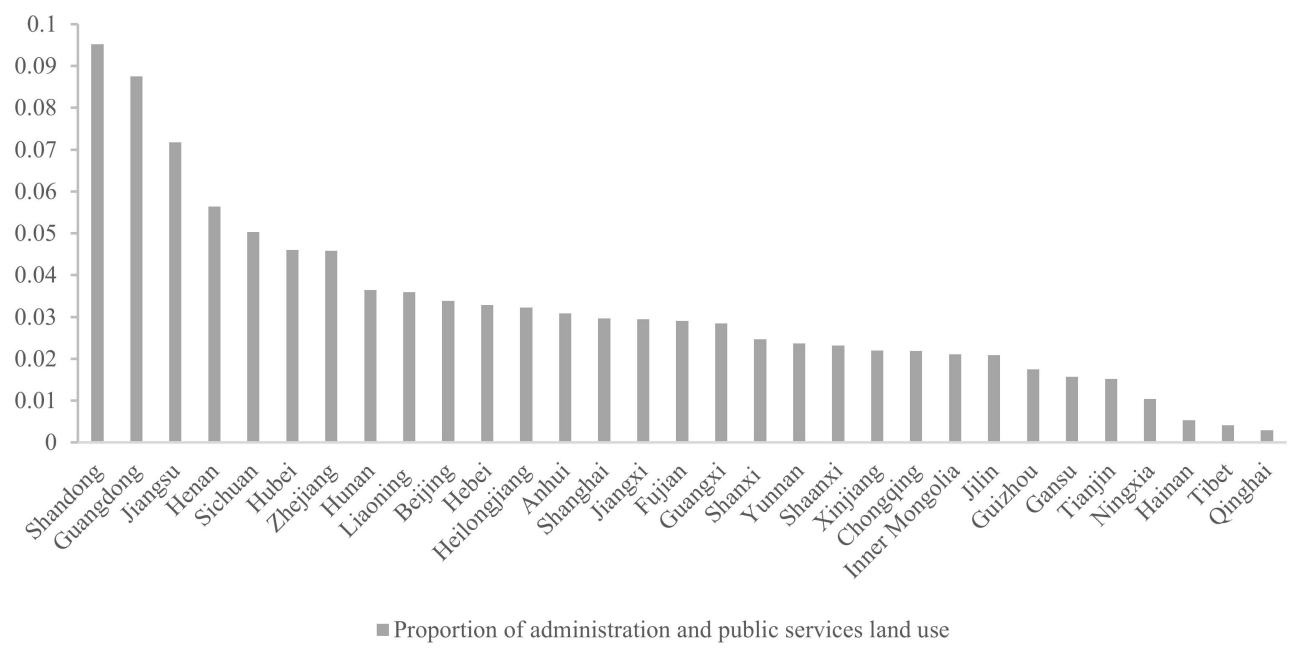

Figure 2. The proportion of administration and public service land use among Chinese provinces in 2017 (data source: Ministry of Housing and Urban-Rural Development of China).

\section{Methodology}

\subsection{The Evaluation Index System of Population Urbanization and Affordable Housing}

We built an evaluation index system to analyze the coupling relationship between population urbanization and affordable housing in Chinese provinces, building on previous index systems [49,50]. The population urbanization index system comprises two indexes: the urban population as a proportion of the total population, and the number of employees in the secondary and tertiary industries as a proportion of the total employees. Two indexes make up the development level of the affordable housing index system: land supply area for affordable housing as a proportion of the total residential land area (AHLA), and local government expenditure on affordable housing as a proportion of the total general budgetary expenditure (AHEP). These indices have been given full consideration regarding data accessibility, relevance, and significance. All data from 2010 to 2017 were downloaded from the China Statistical Yearbook (2011-2018) and China Land and Resources Statistical Yearbook (2011-2018).

We adopt a widely used method, the entropy method, to construct the population urbanization index and affordable housing index for 31 provinces in China. 


\subsection{The CCD Model}

Coupling, which originates from the field of physics, refers to the phenomenon in which two or more indices influence each other through interactions. Other areas, such as climate change, ecological assessment, and urban development, use this method. [51,52].

The coupling degree describes the interactions between two or more systems and external factors.

The coupling degree model is specified as follows:

$$
C=2 \sqrt{f(U) \times g(E)} /[f(U)+g(E)]
$$

where $C$ is the coupling degree and $f(U)$ and $g(E)$ represent the comprehensive development levels of $U$ and $E$, respectively. Nevertheless, the coupling degree is more likely to reflect the similarities between the two systems, lacking reflection on the overall development level and the synergistic effect of each element. We further built a CCD model of $U$ and $E$ as follows:

$$
\begin{gathered}
T=\alpha f(U)+\beta g(E) \\
D=\sqrt{C \times T}
\end{gathered}
$$

where $D$ is the coupling coordination degree, $T$ represents the comprehensive coordination index of $U$ and $E$, and $\alpha$ and $\beta$ are the degrees of the contribution of $U$ and $E$ to urban development, respectively. The contributions of the two systems were assumed to be the same; thus, we set the value $\alpha=\beta=0.5$. According to the degree of coupling coordination $D$, the coordination between $U$ and $E$ can be divided into six stages, as shown in Table 1 [53].

Table 1. Coupling coordination degree and its classification standard.

\begin{tabular}{ccccccc}
\hline$D$ Value & $0<D<0.4$ & $0.4 \leq D<0.5$ & $0.5 \leq D<0.6$ & $0.6 \leq D<0.7$ & $0.7 \leq D<0.8$ & $0.8 \leq D<1$ \\
\hline $\begin{array}{c}\text { Development } \\
\text { Stages }\end{array}$ & $\begin{array}{c}\text { Seriously } \\
\text { unbalanced }\end{array}$ & $\begin{array}{c}\text { Moderately } \\
\text { unbalanced }\end{array}$ & $\begin{array}{c}\text { Slightly } \\
\text { unbalanced }\end{array}$ & $\begin{array}{c}\text { Slightly } \\
\text { balanced }\end{array}$ & $\begin{array}{c}\text { Moderately } \\
\text { balanced }\end{array}$ & $\begin{array}{c}\text { Superior } \\
\text { balance }\end{array}$ \\
\hline
\end{tabular}

\subsection{Mann-Kendall Trend Test}

The present analysis of the time series was carried out using the Mann-Kendall test. This test is a non-parametric statistical method used to detect trends in time series data. The Mann-Kendall test is extremely useful in the detection of data trends, and is widely applicable without the need for a specific distribution test on the data series. In time series analysis, it is also not necessary to specify whether it is a linear trend. [54,55].

The null hypothesis $H_{0}$ indicates the non-existence of a monotonic trend in a variable over time. The equation below explains the test:

$$
S=\sum_{k=1}^{n-1} \sum_{j=k+1}^{n} \operatorname{sgn}\left(x_{j}-x_{k}\right)
$$

where $x_{j}$ and $x_{k}$ represent the values of $x$ in years $j$ and $k$, respectively:

$$
\operatorname{sgn}\left(x_{j}-x_{k}\right)=\left\{\begin{array}{c}
1 \text { if }\left(x_{j}-x_{k}\right)>0 \\
0 \text { if }\left(x_{j}-x_{k}\right)=0 \\
-1 \text { if }\left(x_{j}-x_{k}\right)<0
\end{array}\right.
$$

The equation below calculates the variance of $S$ :

$$
\operatorname{Var}(S)=\frac{1}{18}\left[n(n-1)(2 n+5)-\sum_{p=1}^{q} t_{p}\left(t_{p}-1\right)\left(2 t_{p}+5\right)\right]
$$

where $q$ is the number of tied groups and $t_{p}$ is the number of data values in the $p t h$ group. 
Thus, the statistic is:

$$
Z=\left\{\begin{array}{l}
\frac{S-1}{\sqrt{\operatorname{Var}(S)}} \text { if } S>0 \\
0 \text { if } S=0 \\
\frac{S+1}{\sqrt{\operatorname{Var}(S)}} \text { if } S<0
\end{array}\right.
$$

Counting the number of positive and negative signs during the study period determines the statistic. A zero statistic indicates no change in the trend over time, and the null hypothesis is accepted. A positive $Z$ value indicates an increasing trend, whereas a negative value indicates a decreasing trend. When the absolute value of $Z$ is greater than or equal to $1.28,1.64$, and 2.32 , it indicates that it has passed the $90 \%, 95 \%$, and $99 \%$ confidence tests, respectively.

\subsection{Spatial Autocorrelation Method}

The spatial autocorrelation method can effectively detect the spatial pattern characteristics of the coupling coordination degree, including global and partial spatial autocorrelation [56]. The international spatial autocorrelation method usually adopts the global Moran's I, which examines whether a spatial correlation exists over an entire region. Moran's I is the most popular test statistic for spatial autocorrelation $[57,58]$. The partial spatial autocorrelation model is mainly measured by local Moran's I, which identifies the locations of spatial clusters and spatial outliers. There are five distinguishable categories of local spatial autocorrelation. Two of these are spatial clusters: high values surrounded by high values (high-high) and low values surrounded by low values (low-low). Two are spatial outliers: high values surrounded by low values (high-low) and low values surrounded by high values (low-high). The last type is spatial randomness, which lacks significant spatial patterns in the corresponding weight matrices.

\subsection{Driving Factors Model}

The panel data of 31 provinces in China from 2010 to 2017 were used to test the driving factors. The benchmark regression model was as follows:

$$
D_{i t}=\beta_{0}+\beta_{1} \text { land }_{i t}+\beta_{2} \text { price }_{i t}+\beta_{3} g d p_{i t}+\beta_{4} \text { pergdp } p_{i t}+\beta_{5} \text { ind }_{i t}+\beta_{6} \text { reve }_{i t}+\beta_{7} \text { inco }_{i t}+\varepsilon_{i t}
$$

where $D_{i t}$ is our calculated coupling coordination degree of population urbanization and affordable housing of province $i$ in year $t$. land $d_{i t}$ represents local governments' dependence on land finance, denoted by the proportion of land leasing revenue in the general public budgetary revenue. price $_{i t}$ corresponds to the sale prices of residential, commercial housing. $g d p_{i t}$ and $\operatorname{perg} d p_{i t}$ represent the GDP and GDP per capita, respectively. $i n d u_{i t}$ corresponds to the industrial structure, expressed by the ratio of secondary and tertiary industries. reve $e_{i t}$ denotes general public budgetary revenue. $i n c o_{i t}$ represents the urban-rural income gap, expressed as the ratio of the per capita disposable income of urban households to the per capita net income of rural households. $\beta_{1}, \beta_{2}, \ldots, \beta_{7}$ are regression coefficients, $\beta_{0}$ is a constant term, and $\varepsilon_{i t}$ is an error term.

\section{Results}

\subsection{Coordinated Development Level of Population Urbanization and Affordable Housing}

The collaborative development of population urbanization and affordable housing is required for high-quality urbanization related to residents' wellbeing. The degree of coordination between the two affects the sustainable development of the regional population, society, and economy. The coupling coordination degree is used to measure the relationship between systems in the development process and guarantees the sustainable development of the system. We use the entropy method to calculate the comprehensive score index of population urbanization (Table A1) and affordable housing, and use Equations (1)-(3) to calculate the coupling coordination degree in all provinces in China from 2010 to 2017. The degree of coordination was classified according to the ArcGIS technology platform's 
classification standard, and a spatial distribution map was drawn (Figure 3). We also analyzed the mean value of the coupling coordination degree of population urbanization and affordable housing in various provinces from 2010 to 2017 (Figure 4).
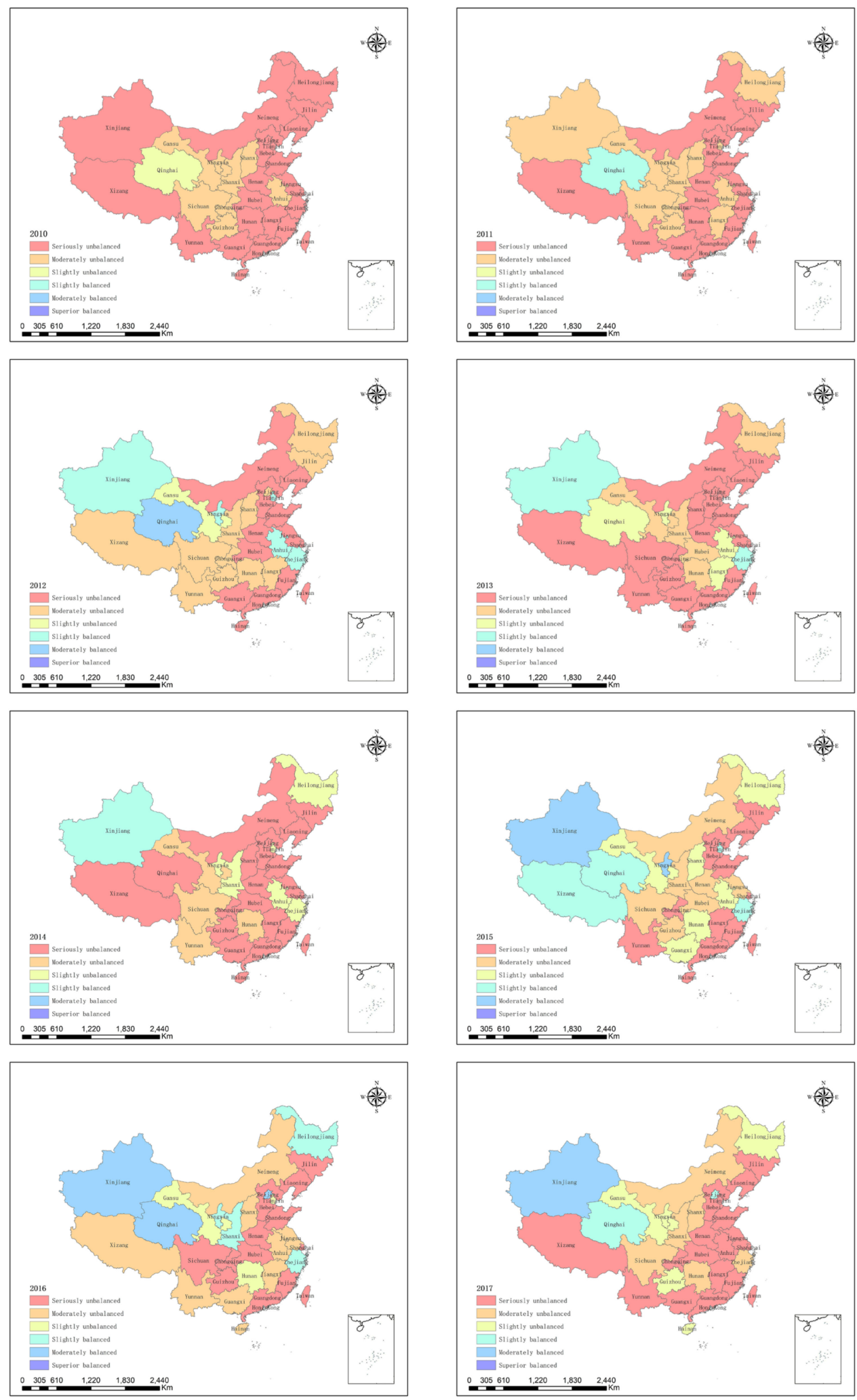

Figure 3. Coordinated development level for population urbanization and affordable housing (from 2010 to 2017). 


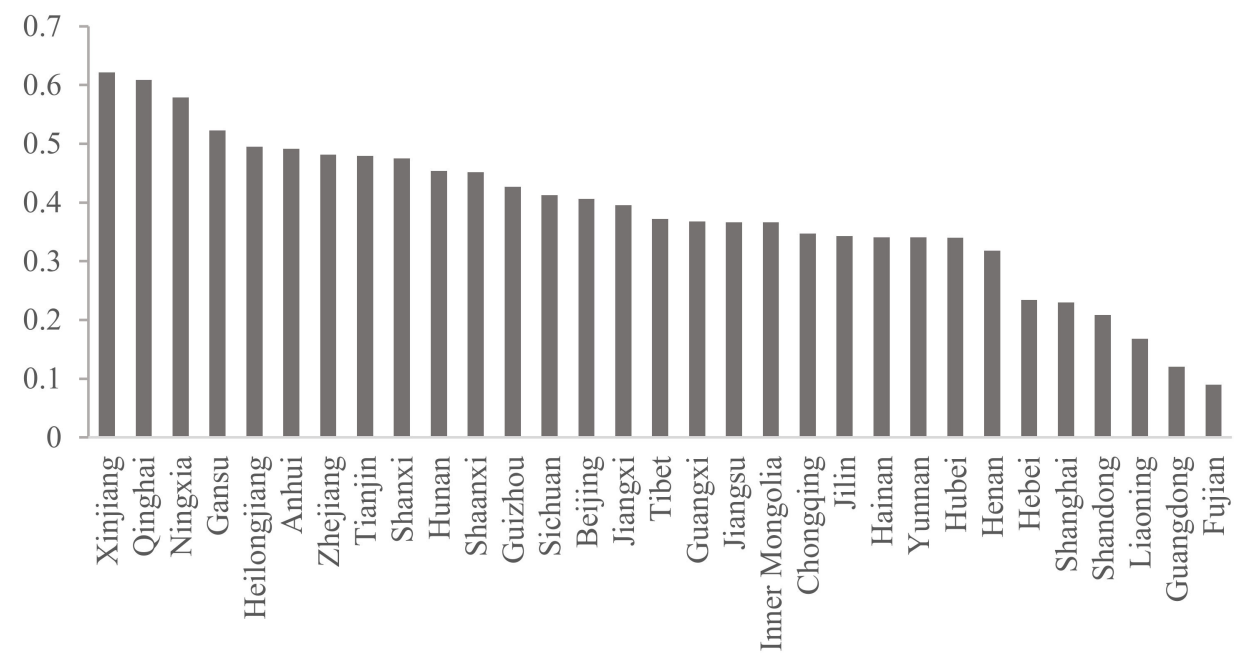

Figure 4. Mean of coordinated development index of population urbanization and affordable housing (from 2010 to 2017).

The regional differentiation of the coordinated development level of population urbanization and affordable housing is apparent. The overall spatial distribution characteristics of the coordination of population urbanization and affordable housing are opposite to the development of its economic level. In other words, places with relatively backward economic growth in the west, such as Xinjiang, Qinghai, Ningxia, and Gansu, that see a high degree of coordination are mainly concentrated in areas; places with better economic development in the east that see a low degree of coordination are mainly concentrated in areas such as Guangdong, Shanghai, and Fujian. Provinces and cities with better economic development have stronger industrial agglomeration capabilities and job opportunities. Many internal migrants have poured into these areas, and there is a high demand for housing. However, these areas often have increased housing prices, migrants cannot afford to buy houses, and their living conditions are poor; thus, they hope to obtain affordable housing from the government. At the same time, in provinces and cities with higher levels of economic development, housing and land prices are high, and the cost of affordable housing is high. It can be seen that affordable housing resources are not well concentrated in areas with high population urbanization rates, that is, areas where the urban population is more focused, and there is a certain degree of spatial mismatch. In addition, more people need protection, and the government's affordable housing supply cannot keep up with the rate of population urbanization, resulting in a low degree of coupling coordination.

Moreover, the degree of coordination in more than half of the provinces showed a changing trend from unbalanced to balanced. For example, Xinjiang changed from a slightly unstable state to a somewhat balanced state from 2010 to 2017. Housing prices are exceptionally high in large cities with an influx of migrants, such as Beijing. In recent years, local governments have paid increasing attention to solving the housing problems of low-income and middle-income groups, young people, and migrants to ensure stable social and economic development. The government has committed to improving the level of affordable housing. Beijing shifted from being seriously unbalanced in 2010 to being slightly balanced in 2017.

\subsection{Temporal Variability of Coordination}

The Mann-Kendall trend test from Equations (4)-(7) tests the changing trend of the coupling and coordination degree of population urbanization and the affordable housing development level. Figure 5 shows the results. The $Z$ value of the national average is 1.608 , which is greater than the critical value of 1.28 at a confidence level of $90 \%$, indicating that the coupling coordination degree has a significant upward trend. From a regional perspective, except for the $Z$ value in the eastern region, which was greater than the critical value at 
a confidence level of $90 \%$, the coupling coordination degree's upward trend between the central and western regions was not noticeable. The provinces and cities in the eastern region have relatively developed economies, high population urbanization, and generally low levels of affordable housing; thus, the degree of coupling coordination between the two is relatively low. Provinces and cities in the central region and, particularly, the western regions have relatively backward economic development, low population urbanization, and relatively high coordination; thus, the upward trend is not apparent. In recent years, affordable housing has continued to increase to protect people's livelihoods, leading to a significant increase in the coordination of population urbanization and affordable housing.
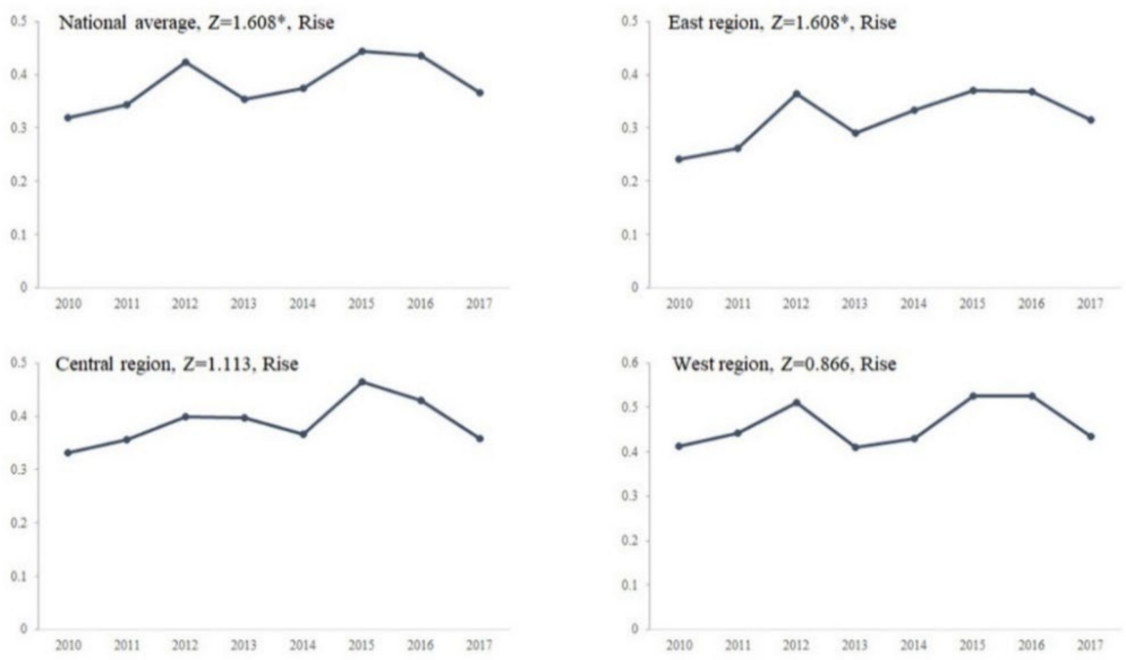

Figure 5. Change trend and test of coupling coordination degree from 2010 to 2017. (Notes: “*” indicates that it has passed the $90 \%$ confidence tests.)

\subsection{Spatial Variability of Coordination}

The spatial autocorrelation index determines spatial dependence. Using the 2010-2017 population urbanization and affordable housing coordination index as the primary data, ArcGIS software measured the global Moran's I index for each year to explore the spatial characteristics of the coordinated development level from 2010 to 2017 (Figure 6). The global Moran's I value of the population urbanization and affordable housing coordination index during this period are all positive, the normal $\mathrm{Z}$ statistic values all pass the $5 \%$ significance level test, and the probability $p$ values are all less than 0.05 , indicating that the coupling coordination degree shows a strong positive spatial correlation; that is, the area surrounding the high-value area of the coordinated development level is also a highvalue area, offering a high distribution pattern, which also means that, since 2010, the coordinated development of China's population urbanization and affordable housing has a specific dependence on spatial distribution, and the research units are not independent. From 2010 to 2011, the global Moran's I value showed an increasing trend, and the spatial agglomeration was abnormally significant, increasing from 0.3524 to 0.3582 ; from 2011 to 2017, the global Moran's I value decreased to 0.1649 but remained positive, indicating that the spatial agglomeration characteristics of the coordination of population urbanization and affordable housing are still apparent. 


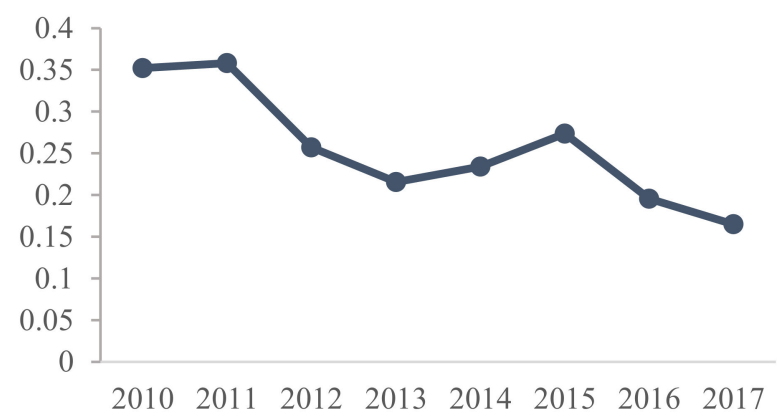

Figure 6. Global Moran's I of coupling coordination degree from 2010 to 2017.

Although the global Moran's I shows that the coupling coordination degree of population urbanization and affordable housing has a high positive correlation in terms of spatial distribution, and the agglomeration characteristics are significant, it does not reveal the concentration and evolution of coordinated development in various provinces and cities. This study used local spatial autocorrelation for further analyses (Figure 7). From 2010 to 2017, the regional spatial agglomeration coordination characteristics were significant and primarily manifested in high-high and low-low agglomeration. Provinces with high agglomeration are mainly concentrated in the northwestern region. This province has a relatively high coupling coordination between population urbanization and affordable housing. Due to the fragile ecological environment, poor geographic location, weak economic foundations, and the apparent urban-rural gap in the northwestern region, the population urbanization level is generally low. In addition, housing and land prices are not high; thus, the cost of affordable housing provided by local governments is not high. Therefore, the current affordable housing level can be coupled well with population urbanization.

Low-low agglomeration provinces are primarily concentrated in the eastern coastal areas, such as Guangdong Province, but the characteristics of such low-low agglomeration will not be evident by 2017. The eastern provinces have developed economies and industries, and many migrants flow into urban areas. The urbanization level of the population was high. However, local governments in this area are under tremendous pressure to implement affordable housing; thus, the increased security level cannot keep up with the population urbanization rate. However, in recent years, local governments have increased their investment in affordable housing to achieve "housing to live" and curb the rapid rise in housing prices, and affordable housing has, thus, improved. Therefore, the low-low agglomeration characteristics in this type of area became insignificant.

\subsection{Driving Factors}

The descriptive statistics of the variables are shown in Table A2. The results of using the panel fixed model (FE) and panel random model (RE) to study the factors driving the coupling coordination degree of population urbanization and affordable housing are shown in Table 2. 

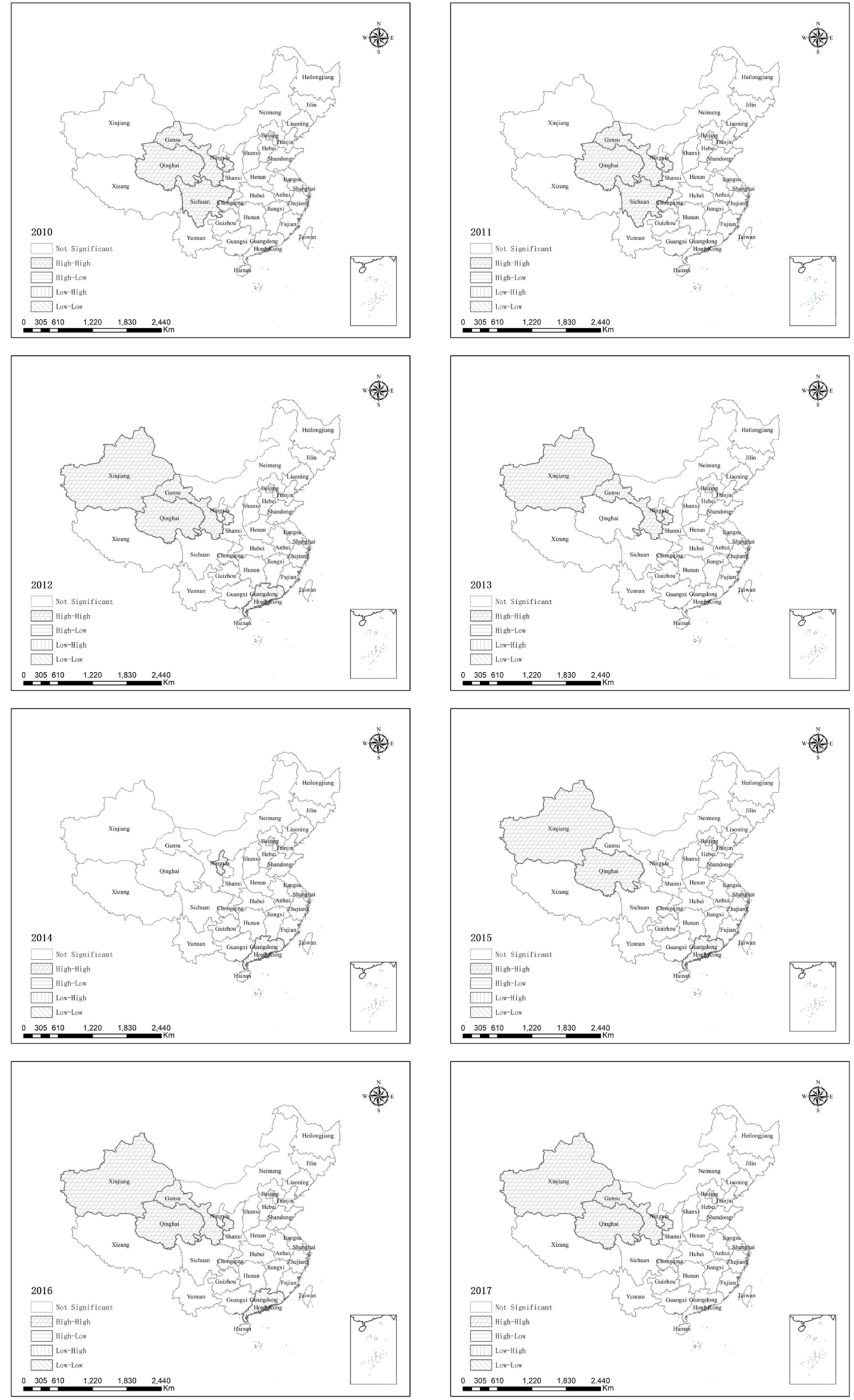

Figure 7. Moran scatter diagram of coordinated development level from 2010 to 2017. 
Table 2. Regression results.

\begin{tabular}{|c|c|c|c|c|}
\hline \multirow{5}{*}{$\begin{array}{l}\text { land }_{i t} \\
\text { price }_{i t} \\
\text { (logarithm) }\end{array}$} & \multicolumn{4}{|c|}{$D_{i t}$} \\
\hline & $-0.233^{* * *}$ & $-0.203^{* * *}$ & $-0.229^{* * *}$ & $-0.189 * * *$ \\
\hline & $(0.039)$ & $(0.042)$ & $(0.038)$ & $(0.040)$ \\
\hline & & $-0.150^{* *}$ & & $-0.129^{* *}$ \\
\hline & & $(0.066)$ & & $(0.054)$ \\
\hline \multirow{2}{*}{$g d p_{i t}$ (logarithm) } & & 0.406 & & $-0.152^{* *}$ \\
\hline & & $(0.369)$ & & $(0.063)$ \\
\hline \multirow{2}{*}{$\operatorname{pergd} p_{i t}(\log a r i t h m)$} & & -0.319 & & $0.230^{* * *}$ \\
\hline & & $(0.374)$ & & $(0.066)$ \\
\hline \multirow{2}{*}{ ind $u_{\text {it }}$} & & -0.768 & & $-0.833^{*}$ \\
\hline & & $(0.704)$ & & $(0.450)$ \\
\hline \multirow{2}{*}{$\begin{array}{l}\text { reve }_{i t} \\
\text { (logarithm) }\end{array}$} & & 0.134 * & & $0.135^{* *}$ \\
\hline & & $(0.070)$ & & $(0.062)$ \\
\hline \multirow[b]{2}{*}{ inco $_{i t}$} & & $0.140^{* * *}$ & & $0.107^{* * *}$ \\
\hline & & $(0.036)$ & & $(0.033)$ \\
\hline \multirow{2}{*}{ Constant } & $0.486^{* * *}$ & 0.616 & $0.484^{* * *}$ & 0.052 \\
\hline & $(0.018)$ & (1.033) & $(0.029)$ & $(0.596)$ \\
\hline Observations & 248 & 248 & 248 & 248 \\
\hline \multirow[t]{2}{*}{$\mathrm{R}$-squared } & 0.141 & 0.243 & 0.141 & 0.231 \\
\hline & $\mathrm{FE}$ & $\mathrm{FE}$ & $\mathrm{RE}$ & $\mathrm{RE}$ \\
\hline
\end{tabular}

Note: Standard errors are in parentheses. ${ }^{* * *} p<0.01,{ }^{* *} p<0.05,{ }^{*} p<0.1$.

Land Finance. Local governments have played a leading role in the construction of affordable housing. Most scholars believe that land finance is the most important factor influencing affordable housing construction levels. Hu and Qian (2017) proposed that land finance primarily affects affordable housing supply through two channels: one of the sources of funds for the construction of affordable housing is land transfer fees; the other is that the construction of affordable housing requires corresponding land. With the rapid rise in urban housing prices, land prices have also continued to rise, and fiscal land revenue is an important supplement to the public fiscal revenue of local governments. It has, thus, become the second fiscal situation [43]. Under the premise that the total supply of urban land is limited, affordable housing land is essentially supplied in the form of free allocation, which reduces the amount of land available for business use, which will undoubtedly reduce the local government's land fiscal revenue and affect its enthusiasm for the construction of affordable housing. We used the proportion of land leasing revenue in general public budgetary revenue as a proxy variable to measure land finance. The greater the value of the revenue, the stronger the dependence of local governments on land finance. The regression results show that local governments' reliance on land finance is negatively correlated with the $1 \%$ significance level of coupling coordination. A possible explanation is that the local governments relying more on land leasing revenue have more incentive to supply land for market-rate housing or industrial use for higher leasing fees, and thus have less motivation to supply land for affordable housing with little returns.

Other Factors. The regression results show that the coefficient of the impact of housing prices on the coupling coordination degree is negative, and the $5 \%$ significance level test shows that a rapid rise in housing prices reduces the coordination level of population urbanization and essential public services to a certain extent. Economic development and population agglomeration will drive the increase in housing prices. Still, high housing prices will bring about high land prices, resulting in higher costs for local governments to implement affordable housing, which will harm housing development. Similar to the United States and other developed countries, real estate taxes are a stable source of local revenue. However, in China, as all land is state-owned, there are no real estate taxes, which means there is a tax reduction for housing transactions, which, in turn, means that local governments are more dependent on land transfer revenue; that is, high land prices can provide adequate revenue for local governments. Moreover, the regression coefficients of local government revenue were positive, indicating that local government revenue 
positively affected the degree of coupling coordination. When the local government has a surplus, there is a strong possibility of increasing the construction of affordable housing and improving the coupling coordination degree, thereby attracting more floating populations, generating more taxes, and forming a good cycle.

\section{Conclusions and Implications}

\subsection{Conclusions}

Given the panel data of all Chinese provinces from 2010 to 2017, this study uses the coupling coordination degree, Mann-Kendall trend test, spatial autocorrelation, and panel fixed model (FE) methods to analyze the temporal and spatial variations in the coordination degree of population urbanization and affordable housing land, and its driving factors, to clarify further the spatial mismatch of affordable housing land resource allocation. From 2010 to 2017, the regional differentiation of the coordinated development level of population urbanization and affordable housing land in China's provinces was evident. The overall spatial distribution characteristics of the coordination of population urbanization and affordable housing land are opposite to the development of its economic level. It can be seen that affordable housing land resources are not well concentrated in areas with high population urbanization rates, that is, areas where the urban population is more concentrated, and there is a certain degree of spatial mismatch. The global Moran's I values of the population urbanization and affordable housing coordination index during 2010-2017 are all positive, indicating that the coupling coordination degree shows a strong positive spatial correlation. The local spatial agglomeration characteristics of coordination are significant and primarily manifest in high-high and low-low agglomerations. Moreover, the local government's dependence on land finance is found to be negatively correlated with the degree of coupling coordination. A possible explanation is that the local governments relying more on land leasing revenue have more incentive to supply land for market-rate housing or industrial use for higher leasing fees, and thus have less motivation to supply land for affordable housing with little returns. At the same time, the impact coefficient of housing prices on the degree of coupling coordination is negative, indicating that a rapid rise in housing prices will reduce the coordination level of population urbanization and basic public services to a certain extent.

\subsection{Implications}

According to the above research, China's affordable housing land supply is a spatial mismatch problem. To improve the affordable housing of the migrant population in cities, help migrant workers complete urban integration quickly, and promote the coordinated development of urbanization and affordable housing resources in various regions, this paper provides the countermeasures outlined below.

First, we find that affordable housing land resources are not well concentrated in areas with high population urbanization rates; that is, there is a certain degree of spatial mismatch. To alleviate this mismatch, a mechanism linking the increase in the supply of affordable housing land with the number of rural-to-urban migrants could be established. Furthermore, it is necessary to control the irrational expansion of urban land scale, deeply tap the potential of existing urban construction land, and accelerate the redevelopment of urban low-efficiency land and the efficient use of urban stock space.

Second, research on spatial variation has found that the coupling coordination of population urbanization and affordable housing land shows a strong positive spatial correlation. Thus, according to the regional functional orientation and environmental carrying capacity of resources, it is necessary to formulate differentiated affordable urban housing land supply standards and promote land development across administrative regions.

Third, the incentive mechanism of local governments should be restructured, and their enthusiasm to supply affordable housing land should be increased. Research on the driving factors has found that the more intensely local government finance depends on land, the lower the coupling coordination. The main factor hindering affordable housing 
land supply is the current fiscal and taxation system. This problem is difficult to solve in the short term, but can be improved by restructuring the local government incentive mechanism, rather than using GDP growth as the sole criterion for the promotion of local officials. Affordable housing should be included in the assessment system. Moreover, the assessment indicators of affordable housing should not simply be considered in terms of quantity; they should be formulated based on how many housing problems have actually been solved.

Author Contributions: Conceptualization, C.H. and D.L.; methodology, C.H.; software, C.H.; formal analysis, D.L.; data curation, J.Y.; writing—original draft preparation, C.H.; writing-review and editing, C.H. and J.Y; visualization, J.Y.; supervision, D.L.; funding acquisition, C.H. All authors have read and agreed to the published version of the manuscript.

Funding: This research was funded by Research Center of Scientific Finance and Entrepreneurial Finance of Ministry of Education of Sichuan Province, grant number KJJR2021-004.

Institutional Review Board Statement: Not applicable.

Informed Consent Statement: Not applicable.

Data Availability Statement: Data used in this study are available upon request.

Conflicts of Interest: The authors declare no conflict of interest. 
Appendix A

Table A1. Comprehensive evaluation index values of population urbanization (PU) and affordable housing (AH).

\begin{tabular}{|c|c|c|c|c|c|c|c|c|c|c|c|c|c|c|c|c|}
\hline & \multicolumn{2}{|c|}{2010} & \multicolumn{2}{|c|}{2011} & \multicolumn{2}{|c|}{2012} & \multicolumn{2}{|c|}{2013} & \multicolumn{2}{|c|}{2014} & \multicolumn{2}{|c|}{2015} & \multicolumn{2}{|c|}{2016} & \multicolumn{2}{|c|}{2017} \\
\hline & PU & AH & PU & AH & PU & $\mathbf{A H}$ & PU & $\mathbf{A H}$ & PU & $\mathbf{A H}$ & PU & $\mathbf{A H}$ & PU & AH & PU & AH \\
\hline Beijing & 0.896 & 0.06 & 0.899 & 0.065 & 0.901 & 0.223 & 0.903 & 0.124 & 0.905 & 0.147 & 0.908 & 0.172 & 0.911 & 0.522 & 0.912 & 0.32 \\
\hline Tianjin & 0.841 & 0.17 & 0.849 & 0.19 & 0.859 & 0.335 & 0.865 & 0.141 & 0.868 & 0.247 & 0.873 & 0.408 & 0.877 & 0.249 & 0.879 & 0.129 \\
\hline Shanxi & 0.543 & 0.192 & 0.555 & 0.212 & 0.57 & 0.204 & 0.581 & 0.143 & 0.587 & 0.112 & 0.594 & 0.27 & 0.604 & 0.21 & 0.611 & 0.165 \\
\hline Inner Mongolia & 0.539 & 0.087 & 0.555 & 0.097 & 0.566 & 0.125 & 0.587 & 0.109 & 0.601 & 0.141 & 0.606 & 0.186 & 0.606 & 0.192 & 0.603 & 0.169 \\
\hline Liaoning & 0.655 & 0.058 & 0.669 & 0.067 & 0.682 & 0.054 & 0.693 & 0.09 & 0.698 & 0.086 & 0.692 & 0.058 & 0.683 & 0.024 & 0.681 & 0.013 \\
\hline Jilin & 0.549 & 0.082 & 0.551 & 0.089 & 0.561 & 0.16 & 0.573 & 0.105 & 0.586 & 0.143 & 0.596 & 0.142 & 0.609 & 0.144 & 0.618 & 0.134 \\
\hline Shanghai & 0.925 & 0.117 & 0.926 & 0.129 & 0.923 & 0.135 & 0.925 & 0.025 & 0.929 & 0.074 & 0.918 & 0.111 & 0.922 & 0.049 & 0.922 & 0.095 \\
\hline Jiangsu & 0.682 & 0.102 & 0.693 & 0.113 & 0.704 & 0.153 & 0.712 & 0.105 & 0.723 & 0.144 & 0.736 & 0.187 & 0.748 & 0.221 & 0.759 & 0.153 \\
\hline Zhejiang & 0.716 & 0.041 & 0.727 & 0.046 & 0.736 & 0.411 & 0.741 & 0.313 & 0.748 & 0.297 & 0.756 & 0.324 & 0.77 & 0.325 & 0.78 & 0.204 \\
\hline Anhui & 0.51 & 0.182 & 0.521 & 0.202 & 0.543 & 0.318 & 0.559 & 0.234 & 0.574 & 0.254 & 0.586 & 0.219 & 0.599 & 0.17 & 0.611 & 0.145 \\
\hline Fujian & 0.635 & 0.032 & 0.651 & 0.038 & 0.666 & 0.037 & 0.676 & 0.023 & 0.686 & 0.017 & 0.697 & 0.021 & 0.706 & 0.025 & 0.715 & 0.03 \\
\hline Jiangxi & 0.531 & 0.141 & 0.546 & 0.155 & 0.565 & 0.179 & 0.577 & 0.267 & 0.589 & 0.128 & 0.602 & 0.12 & 0.616 & 0.157 & 0.63 & 0.097 \\
\hline Shandong & 0.563 & 0.054 & 0.576 & 0.06 & 0.591 & 0.067 & 0.603 & 0.085 & 0.616 & 0.072 & 0.633 & 0.092 & 0.648 & 0.07 & 0.661 & 0.042 \\
\hline Henan & 0.459 & 0.095 & 0.479 & 0.108 & 0.496 & 0.105 & 0.511 & 0.108 & 0.517 & 0.1 & 0.535 & 0.156 & 0.549 & 0.115 & 0.566 & 0.076 \\
\hline Hubei & 0.514 & 0.075 & 0.529 & 0.084 & 0.544 & 0.114 & 0.557 & 0.153 & 0.575 & 0.133 & 0.591 & 0.193 & 0.606 & 0.117 & 0.619 & 0.119 \\
\hline Guangdong & 0.703 & 0.031 & 0.708 & 0.035 & 0.714 & 0.032 & 0.72 & 0.03 & 0.724 & 0.037 & 0.73 & 0.053 & 0.746 & 0.036 & 0.753 & 0.06 \\
\hline Guangxi & 0.426 & 0.121 & 0.44 & 0.136 & 0.449 & 0.123 & 0.457 & 0.09 & 0.47 & 0.117 & 0.482 & 0.214 & 0.49 & 0.176 & 0.497 & 0.077 \\
\hline Hainan & 0.497 & 0.077 & 0.507 & 0.082 & 0.519 & 0.093 & 0.546 & 0.063 & 0.554 & 0.133 & 0.568 & 0.137 & 0.578 & 0.187 & 0.589 & 0.24 \\
\hline Chongqing & 0.56 & 0.187 & 0.581 & 0.207 & 0.601 & 0.194 & 0.616 & 0.093 & 0.631 & 0.1 & 0.648 & 0.098 & 0.667 & 0.124 & 0.681 & 0.065 \\
\hline Sichuan & 0.474 & 0.147 & 0.488 & 0.17 & 0.504 & 0.18 & 0.515 & 0.133 & 0.528 & 0.175 & 0.541 & 0.166 & 0.556 & 0.123 & 0.569 & 0.162 \\
\hline Guizhou & 0.329 & 0.154 & 0.343 & 0.164 & 0.357 & 0.145 & 0.373 & 0.136 & 0.394 & 0.12 & 0.412 & 0.192 & 0.434 & 0.141 & 0.452 & 0.211 \\
\hline Yunnan & 0.369 & 0.069 & 0.385 & 0.072 & 0.411 & 0.17 & 0.423 & 0.092 & 0.438 & 0.148 & 0.455 & 0.13 & 0.46 & 0.211 & 0.48 & 0.056 \\
\hline Tibet & 0.332 & 0.1 & 0.348 & 0.136 & 0.369 & 0.151 & 0.378 & 0.061 & 0.397 & 0.072 & 0.423 & 0.345 & 0.454 & 0.154 & 0.466 & 0.106 \\
\hline Shaanxi & 0.515 & 0.15 & 0.53 & 0.171 & 0.494 & 0.168 & 0.51 & 0.187 & 0.525 & 0.252 & 0.543 & 0.195 & 0.555 & 0.308 & 0.569 & 0.177 \\
\hline Gansu & 0.371 & 0.189 & 0.379 & 0.209 & 0.391 & 0.311 & 0.404 & 0.184 & 0.418 & 0.175 & 0.431 & 0.239 & 0.444 & 0.309 & 0.458 & 0.291 \\
\hline Qinghai & 0.509 & 0.274 & 0.527 & 0.306 & 0.545 & 0.458 & 0.55 & 0.247 & 0.56 & 0.138 & 0.568 & 0.38 & 0.579 & 0.583 & 0.589 & 0.375 \\
\hline Ningxia & 0.49 & 0.198 & 0.504 & 0.211 & 0.51 & 0.357 & 0.522 & 0.244 & 0.541 & 0.303 & 0.555 & 0.497 & 0.565 & 0.365 & 0.586 & 0.224 \\
\hline Xinjiang & 0.466 & 0.142 & 0.47 & 0.161 & 0.473 & 0.493 & 0.487 & 0.413 & 0.5 & 0.395 & 0.513 & 0.496 & 0.523 & 0.513 & 0.542 & 0.457 \\
\hline
\end{tabular}




\section{Appendix B}

Table A2. Descriptive statistics.

\begin{tabular}{|c|c|c|c|c|c|}
\hline Variable & Obs & Mean & Std.Dev. & Min & $\operatorname{Max}$ \\
\hline $\begin{array}{l}\text { Coupling coordination degree of } \\
\text { population urbanization and affordable } \\
\text { housing }\end{array}$ & 248 & 0.382 & 0.159 & 0.043 & 0.784 \\
\hline $\begin{array}{l}\text { Proportion of land leasing revenue in the } \\
\text { general public budgetary revenue }\end{array}$ & 248 & 0.443 & 0.228 & 0.068 & 1.395 \\
\hline $\begin{array}{l}\text { Residential commercial housing sales } \\
\text { price (CNY/square meter) }\end{array}$ & 248 & 6586 & 4253 & 2896 & 32,140 \\
\hline GDP (CNY 100 million) & 248 & 20,983 & 17,120 & 507 & 89,705 \\
\hline GDP per capita (CNY) & 248 & 48,128 & 23,467 & 13,119 & 128,994 \\
\hline Ratio of secondary and tertiary industries & 248 & 0.899 & 0.051 & 0.739 & 0.996 \\
\hline $\begin{array}{l}\text { General public budgetary revenue (CNY } \\
100 \text { million) }\end{array}$ & 248 & 2261 & 1906 & 37 & 11,315 \\
\hline $\begin{array}{l}\text { Ratio of per capita disposable income of } \\
\text { urban households to the per capita net } \\
\text { income of rural households }\end{array}$ & 248 & 2.732 & 0.462 & 1.845 & 4.073 \\
\hline
\end{tabular}

\section{References}

1. Xu, H.; Jiao, M. City size, industrial structure and urbanization quality-A case study of the Yangtze River Delta urban agglomeration in China. Land Use Policy 2021, 111, 105735. [CrossRef]

2. Davenport, R.J. Urbanization and mortality in Britain. Econ. Hist. Rev. 2020, 73, 455-485. [CrossRef]

3. Gu, K.; Wall, G. Rapid urbanization in a transitional economy in China: The case of Hainan Island. Singap. J. Trop. Geogr. 2007, 28, 158-170. [CrossRef]

4. Chen, J.; Hao, Q.; Stephens, M. Assessing housing affordability in post-reform China: A case study of Shanghai. Hous. Stud. 2010, 25, 877-901. [CrossRef]

5. Yang, Z.; Shen, Y. The affordability of owner-occupied housing in Beijing. J. Hous. Built. Environ. 2008, 23, 317-335. [CrossRef]

6. Bohle, H.G.; Downing, T.E.; Watts, M.J. Climate change and social vulnerability: Toward a sociology and geography of food insecurity. Glob. Environ. Chang. 1994, 4, 37-48. [CrossRef]

7. Paavola, J. Livelihoods, vulnerability and adaptation to climate change in Morogoro, Tanzania. Environ. Sci. Policy 2008, 11, 642-654. [CrossRef]

8. Maccini, S.; Yang, D. Under the weather: Health, schooling, and economic consequences of early-life rainfall. Am. Econ. Rev. 2009, 99, 1006-1026. [CrossRef] [PubMed]

9. He, C.; Chen, T.; Mao, X.; Zhou, Y. Economic transition, urbanization and population redistribution in China. Habitat Int. 2016, 51, 39-47. [CrossRef]

10. Shi, W.; Chen, J.; Wang, H. Affordable housing policy in China: New developments and new challenges. Habitat Int. 2016, 54, 224-233. [CrossRef]

11. Yang, Z.; Chen, J. Housing Affordability and Housing Policy in Urban China; Springer: Berlin/Heidelberg, Germany, 2014. [CrossRef]

12. Mak, S.W.K.; Choy, L.H.T.; Ho, W.K.O. Privatization, housing conditions and affordability in the people's republic of China. Habitat Int. 2007, 31, 177-192. [CrossRef]

13. Zou, Y. Contradictions in China's affordable housing policy: Goals vs. structure. Habitat Int. 2014, 41, 8-16. [CrossRef]

14. Li, Y.; Li, Y.; Zhou, Y.; Shi, Y.; Zhu, X. Investigation of a coupling model of coordination between urbanization and the environment. J. Environ. Manag. 2012, 98, 127-133. [CrossRef]

15. Lin, X.; Lu, C.; Song, K.; Su, Y.; Lei, Y.; Zhong, L.; Gao, Y. Analysis of coupling coordination variance between urbanization quality and eco-environment pressure: A case study of the west Taiwan strait urban agglomeration, China. Sustainability 2020, 12, 2643. [CrossRef]

16. Fang, C.; Liu, H.; Wang, S. The coupling curve between urbanization and the eco-environment: China's urban agglomeration as a case study. Ecol. Ind. 2021, 130, 108107. [CrossRef]

17. United Nations. World Urbanization Prospects: The 2018 Revision, Key Facts; United Nations, Ed.; Department of Economic and Social Affairs: New York City, NY, USA, 2018; Available online: https:/ / esa.un.org/unpd/wup/Publications/Files/WUP2018-KeyFacts (accessed on 5 February 2022).

18. Davis, J.C.; Henderson, J.V. Evidence on the political economy of the urbanization process. J. Urban Econ. 2003, 53, 98-125. [CrossRef]

19. Borck, R.; Pfluger, M.; Wrede, M. A simple theory of industry location and residence choice. J. Econ. Geogr. 2010, 10, 913-940. [CrossRef]

20. Greunz, L. Industrial structure and innovation-evidence from European regions. J. Evolut. Econ. 2004, 14, 563-592. [CrossRef] 
21. Glaeser, E.L.; Resseger, M.G. The complementarity between cities and skills. J. Reg. Sci. 2010, 50, 221-244. [CrossRef]

22. Henderson, J.V.; Storeygard, A.; Deichmann, U. Has climate change driven urbanization in Africa? J. Dev. Econ. 2017, 124, 60-82. [CrossRef]

23. Liu, Y.; Yao, C.; Wang, G.; Bao, S. An integrated sustainable development approach to modeling the eco-environmental effects from urbanization. Ecol. Indic. 2011, 11, 1599-1608. [CrossRef]

24. Park, H.; Fan, P.; John, R.; Chen, J. Urbanization on the Mongolian Plateau after economic reform: Changes and causes. Appl. Geogr. 2017, 86, 118-127. [CrossRef]

25. Mulligan, G.F. Revisiting the urbanization curve. Cities 2013, 32, S58-S67. [CrossRef]

26. Olsson, G. Explanation, prediction, and meaning variance: An assessment of distance interaction models. Econ. Geogr. 1970, 46, 223-233. [CrossRef]

27. Ji, X.; Wu, J.; Zhu, Q.; Sun, J. Using a hybrid heterogeneous DEA method to benchmark China's sustainable urbanization: An empirical study. Ann. Oper. Res. 2019, 278, 281-335. [CrossRef]

28. Li, X.; Lu, Z. Quantitative measurement on urbanization development level in urban Agglomerations: A case of JJJ urban agglomeration. Ecol. Indic. 2021, 133, 108375. [CrossRef]

29. Alig, R.J.; Kline, J.D.; Lichtenstein, M. Urbanization on the US landscape: Looking ahead in the 21st century. Landsc. Urban Plan. 2004, 69, 219-234. [CrossRef]

30. Short, J.R. Liquid City: Megalopolis and the Contemporary Northeast; Resources for the Future Press: Washington, DC, USA, 2007. [CrossRef]

31. Wilson, S.G.; Plane, D.A.; Mackun, P.J.; Fischetti, T.R.; Goworowska, J. Patterns of Metropolitan and Micropolitan Population Change: 2000 to 2010, C2010SR-01; U.S. Census Bureau, U.S. Government Printing Office: Washington, DC, USA, 2012. Available online: https: / / www.mendeley.com/catalogue/64060a68-3567-34a3-b17b-8d5e4ca1b7d5/ (accessed on 5 February 2022).

32. Pacione, M. Urban Geography: A Global Perspective; Routledge: London, UK, 2009. [CrossRef]

33. Goldin, C.; Katz, F. The Race between Education and Technology; The Belknap Press of Harvard University Press: Cambridge, UK, 2008. [CrossRef]

34. Lin, Y.; Li, Y.; Ma, Z. Exploring the interactive development between population urbanization and land urbanization: Evidence from Chongqing, China (1998-2016). Sustainability 2018, 10, 1741. [CrossRef]

35. Li, K.; Ma, Z.; Liu, J. A new trend in the Space-Time distribution of cultivated land occupation for construction in China and the impact of population urbanization. Sustainability 2019, 11, 5089. [CrossRef]

36. Hui, E.C.M.; Wong, F.K.W. Affordable housing in China. Habitat Int. 2006, 30, 275-276. [CrossRef]

37. Chen, J.; Yang, Z.; Wang, Y.P. The new Chinese model of public housing: A step forward or backward? Hous. Stud. 2014, 29, 534-550. [CrossRef]

38. Zhou, J.; Ronald, R. Housing and welfare regimes: Examining the changing role of public housing in China. Hous. Theory Soc. 2017, 34, 253-276. [CrossRef]

39. Dang, Y.; Liu, Z.; Zhang, W. Land-based interests and the spatial distribution of affordable housing development: The case of Beijing, China. Habitat Int. 2014, 44, 137-145. [CrossRef]

40. Gan, X.; Zuo, J.; Ye, K.; Li, D.; Chang, R.; Zillante, G. Are migrant workers satisfied with public rental housing? A study in Chongqing, China. Habitat Int. 2016, 56, 96-102. [CrossRef]

41. Gan, X.; Zuo, J.; Baker, E.; Chang, R.; Wen, T. Exploring the determinants of residential satisfaction in public rental housing in China: A case study of Chongqing. J. Hous. Built. Environ. 2019, 34, 869-895. [CrossRef]

42. Huang, Z.; Du, X. Assessment and determinants of residential satisfaction with public housing in Hangzhou, China. Habitat Int 2015, 47, 218-230. [CrossRef]

43. Hu, F.Z.; Qian, J. Land-based finance, fiscal autonomy and land supply for affordable housing in urban China: A prefecture-level analysis. Land Use Policy 2017, 69, 454-460. [CrossRef]

44. Chan, K.W.; Buckingham, W. Is China abolishing the hukou system? China Quart. 2008, 195, 582-606. [CrossRef]

45. Huang, Y.; Yi, C. Invisible migrant enclaves in Chinese cities: Underground living in Beijing, China. Urban Stud. 2015, 52, 2948-2973. [CrossRef]

46. Wang, Y.; Otsuki, T. Do institutional factors influence housing decision of young generation in urban China: Based on a study on determinants of residential choice in Beijing. Habitat Int. 2015, 49, 508-515. [CrossRef]

47. Yu, L.; Cai, H. Challenges for housing rural-to-urban migrants in Beijing. Habitat Int. 2013, 40, 268-277. [CrossRef]

48. Pollitt, C.; Bouckaert, G. Public Management Reform: A Comparative Analysis—Into the Age of Austerity; Oxford University Press: Oxford, UK, 2017; Available online: https://www.onacademic.com/detail/journal_1000033305111199_bdf1.html (accessed on 5 February 2022).

49. Zang, L.; Su, Y. Internal coordinated development of China's urbanization and its spatiotemporal evolution. Sustainability 2019, 11, 626. [CrossRef]

50. Wang, Z.; Shi, C.; Li, Q.; Wang, G. Coupling trending analysis about urbanization and urban resource in Beijing. Energy Proc. 2011, 5, 1589-1596. [CrossRef]

51. Nguyen Duc, K.; Ancev, T.; Randall, A. Evidence of climatic change in Vietnam: Some implications for agricultural production. J. Environ. Manag. 2019, 231, 524-545. [CrossRef] [PubMed] 
52. Wu, Y.; Zhu, X.; Gao, W.; Qian, F. The spatial characteristics of coupling relationship between urbanization and eco-environment in the pan Yangtze river delta. Energy Proc. 2018, 152, 1121-1126. [CrossRef]

53. Mohr, S.; Kunz, M. Recent trends and variabilities of convective parameters relevant for hail events in Germany and Europe. Atmos. Res. 2013, 123, 211-228. [CrossRef]

54. Tabari, H.; Hosseinzadeh, T.P. Analysis of trends in temperature data in arid and semi-arid regions of Iran. Global Planet. Chang. 2011, 79, 1-10. [CrossRef]

55. Yue, S.; Wang, C. The Mann-kendall test modified by effective sample size to detect trend in serially correlated hydrological series. Water Resour. Manag. 2004, 18, 201-218. [CrossRef]

56. Jindal, P.; Thapliyal, P.K.; Shukla, M.V.; Sharma, S.K.; Mitra, D. Satellite based trend analysis of few atmospheric parameters over the Indian region. Adv. Space Res. 2019, 64, 2245-2268. [CrossRef]

57. Zhang, T.; Lin, G. A decomposition of moran's I for clustering detection. Comput. Stat. Data Anal. 2007, 51, 6123-6137. [CrossRef]

58. Zhang, T. On Moran's I coefficient under heterogeneity. Comput. Stat. Data Anal. 2016, 95, 83-94. [CrossRef] 